\title{
Effects of soil and water conservation technologies on the establishment, growth and survival of three tree species
}

\author{
Carlos Ovalle ${ }^{1}$, Ingrid Martínez ${ }^{2 *}$, Hamil Uribe ${ }^{1}$, Christian Prat $^{3}$, Alejandro del Pozo ${ }^{4}$, \\ Natalia Valderrama ${ }^{5}$, and Germán Ruíz ${ }^{6}$ \\ 'Instituto de Investigaciones Agropecuarias, INIA Quilamapu, Av. Vicente Méndez 515, Chillán, Chile. \\ ${ }^{2}$ Instituto de Investigaciones Agropecuarias, INIA Remehue, Ruta 5 Norte km 8, Osorno, Chile. \\ "Corresponding author (ingrid.martinez@inia.cl). \\ ${ }^{3}$ Institut de Recherche pour le Développement (IRD France), 44 Bd de Dunkerque, 13572 Marseille Cedex 02, France. \\ ${ }^{4}$ Universidad de Talca, Facultad de Ciencias Agrarias, Av. Lircay s/n, Talca, Chile. \\ ${ }^{5}$ Universidad de Concepción, Facultad de Ingeniería Agrícola, Av. Vicente Méndez 595, Chillán, Chile. \\ ${ }^{6}$ Servicio Agrícola y Ganadero (SAG), División de Protección de los Recursos Naturales Renovables, Paseo Bulnes 140, Santiago, Chile.
}

Received: 3 June 2020; Accepted: 25 August 2020; doi:10.4067/S0718-58392020000400640

\begin{abstract}
The agroforestry activity of central Chile is developed under Mediterranean climate, characterized by long periods of water deficit conditions, particularly on hillsides with degraded and compacted soils. The objective of this study was to assess the effect of two soil and water conservation techniques on soil water content (SWC) and in plant growth and survival of three tree species. The conservation techniques evaluated were subsoiling with contour ridges (SB) and infiltration trench (IT), and a control treatment without soil management (CO). Growth and survival of Cytisus proliferus L. f. var. proliferus, Quercus suber L. and Quillaja saponaria Molina were examined. The experimental area was sown with a mixture of annual legumes. Conservation systems allowed higher SWC especially in years of higher rainfall (2008 and 2009) at 20-40 and 40-60 cm depth. SWC was higher in SB followed by IT and CO, whereas at 60-80 and 80-100 $\mathrm{cm}$ depth differences were significant only in the driest years. After $4 \mathrm{yr}$, plant survival of C. proliferus and $Q$. suber was similar in the three establishment systems (97\% and $87 \%$, respectively), but survival of $Q$. saponaria was lower in CO. Plant height in C. proliferus was higher in IT > SB > CO, while Q. suber was higher in $\mathrm{SB}>\mathrm{IT}>\mathrm{CO}$; Q. saponaria had similar growth in SB and IT conservation systems but it was significantly higher $(\mathrm{P}<0.05)$ than in $\mathrm{CO}$. It is concluded that subsoiling with ridges has a great potential for degraded and compact soils of the Mediterranean region, allowing higher SWC in the profile and better tree establishment and growth.
\end{abstract}

Key words: Cytisus proliferus, infiltration trench, Quercus suber, Quillaja saponaria, subsoiling.

\section{INTRODUCTION}

Practices such as agroforestry and conservation agriculture systems have the potential to conserve soil and water resources, improve ecosystems services and restore soil organic C (Alfaro et al., 2018) through increased C inputs from higher biomass productivity (Corbeels et al., 2019; Kumar et al., 2020). However, agroforestry systems in the Mediterranean climate region of central Chile are highly dependent on precipitation, which is concentrated in winter. This zone is characterized by moderate to steep slopes and severely degraded soils (CIREN, 2010), which influence the establishment of forest species with the ability to withstand dry periods (5-6 mo) in highly compacted soils. On the other hand, Mediterranean environments can be dominated by episodes of torrential rain in some years producing a negative impact 
on soil erodability (Aranda et al., 2012; Biazin et al., 2012; Martínez et al., 2012; Camarasa-Belmonte and Soriano, 2014).

Due to this clear seasonality, water availability is one of the limiting factors in tree growth (Vicente-Serrano et al., 2010). In this scenery, the adoption of erosion-preventative measures is more relevant now than ever before (Lal, 2019). For reforestation programs to be successful, it is therefore paramount soil and water conservation structures, as well as, to select species that adapt to low fertility compacted soils, high temperature variation, and are resistant to extreme drought conditions. It is predicted that climate change in the next decades will increase in global average temperature, as well as, the frequency and severity of droughts, especially in arid and semi-arid ecosystems where the projections indicate earlier and more prolonged droughts (Rolo and Moreno, 2019). This will negatively affect the sustainability and productivity of forests in Mediterranean environments (Aranda et al., 2012; Kumar et al., 2020).

This background information should emphasize the importance of water as a limiting factor for the future of forest areas and as a priority in planning new systems. Using conservation systems under these conditions allows the establishment of a more favorable water balance by increasing soil water infiltration, soil organic $\mathrm{C}$ and promoting its availability for agricultural and forest species during the dry period (Govaerts et al., 2009; Frankl et al., 2012; Labrière et al., 2015). Among the most used conservation techniques in forest systems, infiltration trenches help to reduce surface runoff and increase infiltration and soil water content (SWC) around the trenches (Makurira et al., 2009; 2011). Contour lines have also shown a positive effect in increasing SWC by capturing rainwater, which allows better tree establishment (Mupangwa et al., 2012; Kumar et al., 2020).

A number of multipurpose woody species can be used in agroforestry systems in central Chile (Ovalle et al., 2006). Among them is Cytisus proliferus L. f. var. proliferus (tagasaste), Fabaceae, an evergreen shrub from the Canary Islands, with good adaptation to degraded and low fertility soils, and high palatable leaves for animal grazing (de Miguel et al., 2016). Another species is Quercus suber L. (alcornoque), Fagaceae, an evergreen tree widely distributed in the Mediterranean basin (Pausas et al., 2009), which is mainly used for cork production but also its acorns are used for animal feeding (Gaspar et al., 2007); in Chile $Q$. suber growths well in granitic soil of the Mediterranean region (de Miguel et al., 2016). Finally, Quillaja saponaria Molina (quillay), Quillajaceae, is an evergreen tree endemic to the Mediterranean zone in Chile with interesting uses in the agroindustrial market (Moya et al., 2010).

The objective of this study was to evaluate the effect of two soil conservation techniques and compare them with a control treatment on soil water content, as well as their effect on the survival and growth of three tree species: Cytisus proliferus, Quercus suber and Quillaja saponaria.

\section{MATERIALS AND METHODS}

\section{Site description}

The study area was located at the Cauquenes Experimental Center (35 $97^{\prime}$ S, $72^{\circ} 24^{\prime}$ W; $140 \mathrm{~m}$ a.s.l.) owned by the Instituto de Investigaciones Agropecuarias (INIA) located in the interior dryland of the Maule Region, Chile. Long-term annual precipitation is $695 \mathrm{~mm}$ and $5 \mathrm{mo}$ of drought period; rainfall is mainly concentrated in June-August (Figure 1).

Figure 1. Monthly rainfall distribution from 2007 to 2009 compared with 44-yr mean precipitation in Cauquenes, Chile.

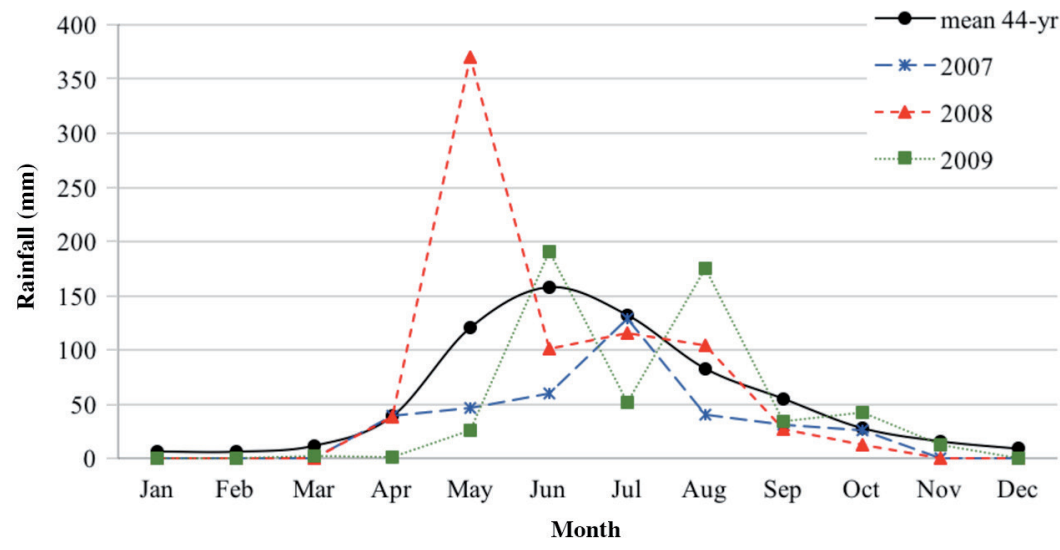


Annual mean temperature is $14.7^{\circ} \mathrm{C}$ with a minimum of $4.7^{\circ} \mathrm{C}$ in July and maximum of $27^{\circ} \mathrm{C}$ in January (del Pozo and del Canto, 1999). The soil is classified as an Alfisol Ultic Palexeralfs (Stolpe, 2006) and is made up of granite origin materials, low organic matter (1.5\%), and bulk density is $1.5-2.0 \mathrm{Mg} \mathrm{m}^{-3}$. Previous management of the site corresponded to natural pasture with Suffolk Down sheep grazing.

\section{Experimental design}

Experimental plots of $1500 \mathrm{~m}^{2}(30 \times 50 \mathrm{~m})$ were set up in a hillside with a $25 \%$ slope in 2007 and followed up until 2011. The treatments were: subsoiling with contour ridges (SB), which was subsoiled at a mean depth of $40 \mathrm{~cm}$ carried out in 2007 followed by the building of a contour ridge (15-20 cm high) used for tree planting (Figure 2a); infiltration trench (IT) (Figure 2b), which consisted in digging a trench (40 $\mathrm{cm}$ deep) with a contour ridge ( $40 \mathrm{~cm}$ high) used for tree planting; and a control treatment (CO) without soil management and with tree planting (Figure 2c). All treatments had three replicates with a distance of $12.5 \mathrm{~m}$ between each system (Figure 3). Three multipurpose species were established: Cytisus proliferus L. f. var. proliferus, Quercus suber L. and Quillaja saponaria Molina, which is a multipurpose woody species, with a spacing of $1 \mathrm{~m}$ accommodated 90 plants in each treatment $( \pm 30 \mathrm{~cm}$ tall). The experimental area was sown with a mixture of annual legumes in May 2007. The mixture contained balansa clover (Trifolium michelianum Savi), subterranean clover (T. subterraneum L.) 'Gosse' and 'Clare', and burr medic (Medicago polymorpha L.) and was characterized for its good persistence in granitic soils of the Mediterranean region.

Figure 2. Treatments disposal established at the field experiment: subsoiling with contour ridges (A), infiltration trenches (B), and control (C).
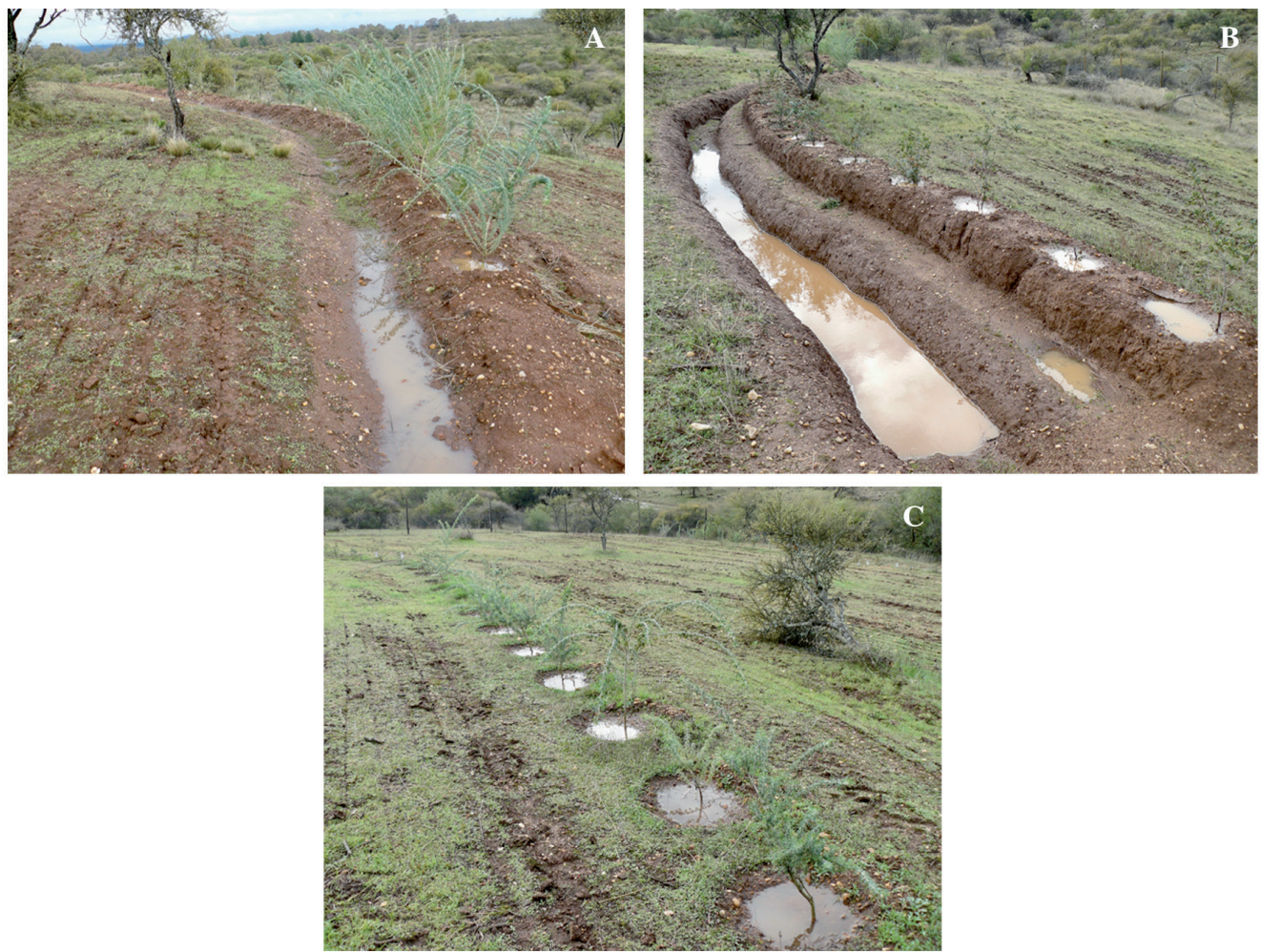

Soil water content (SWC) was analyzed during 2007-2009 using a split-split-plot experimental design with three replicates: conservation systems (large plot), depth (subplot), and tube location (sub-subplot) were considered in the linear model; DatexDepth, Depth×Tube location, and three-way interactions were also evaluated. Growth variables: height, trunk diameter, crown diameter and tree survival were analyzed during 2007-2011 by a random split-plot design with three replicates: woody species (main plot), conservation systems (subplot), and the interactions between factors were considered. Data were processed with the SAS software program version 9.1.3 Service Pack, 2002-2003 (SAS Institute, Cary, North Carolina, USA) by the GLM procedure for ANOVA and Tukey's test to compare means of significant values ( $\mathrm{p} \leq 0.05$ ). 
Figure 3. Field experiment layout and plot size for each treatment.

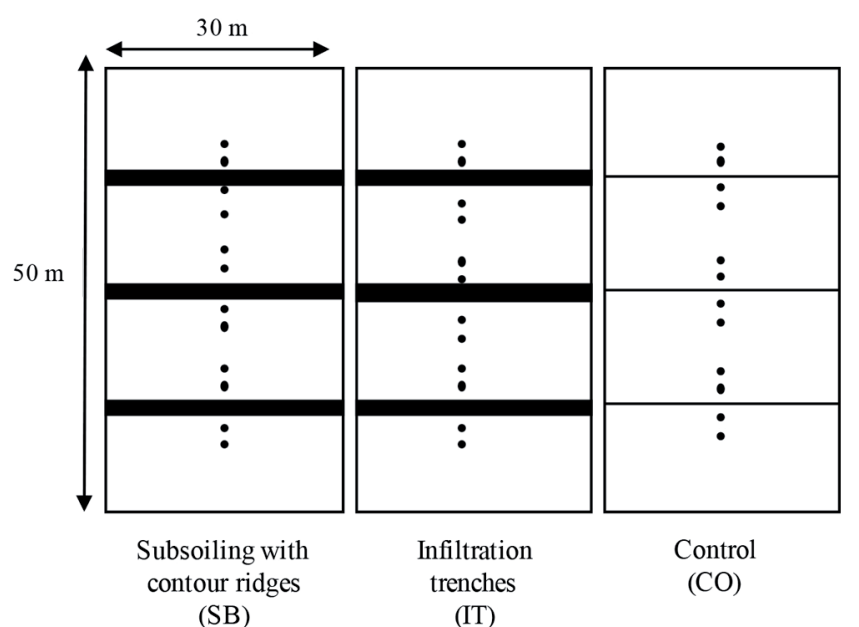

Black circles are location of aluminum access tubes.

\section{Soil water content (SWC) and tree growth measurement}

Soil water content was determined with a neutron gauge (Troxler 4300; Troxler Electronic Laboratories, Research Triangle Park, North Carolina, USA) in aluminum access tubes with a diameter of $50 \mathrm{~mm}$ and $120 \mathrm{~cm}$ long. These tubes were installed vertically at a $110 \mathrm{~cm}$ depth when the trial was established (Figure 3). Four tubes were installed in each replicate and located at a distance of 50 and $100 \mathrm{~cm}$ up and down each treatment (Figure 4). Readings were taken every $20 \mathrm{~cm}$ up to the $100 \mathrm{~cm}$ depth, readings started at the end of each winter rainy season at 1- to 3 -wk intervals. The period from January to April was not considered given the Mediterranean climate zone and the fact that SWC stabilizes during the dry period. Six extra tubes were installed to calibrate the neutron probe. Two tubes were evaluated at the start, in the middle, and at the end of the SWC evaluation period. Samples to determine volumetric SWC were taken at $30 \mathrm{~cm}$ distance from each tube at the same depth as the readings. A linear calibration curve was obtained with the SWC results and the respective probe readings. Equations of the straight line and their respective adjustment coefficients $\left(\mathrm{R}^{2}\right)$ were determined for the 20,40,60,80, and $100 \mathrm{~cm}$ soil depths. Gravimetric water content at each depth was converted into volumetric water content by the corresponding apparent density. The regression analysis between soil volumetric water content and the neutron probe reading was $\mathrm{R}^{2}=0.84$. Trees were planted in autumn 2007 when the trial was established. After the first year, the following parameters were evaluated annually (2008-2011): height, trunk diameter, and DM (at $60 \mathrm{~cm}$ height for each species). Survival rate (\%) was evaluated in the autumn of 2008 and 2011.

Figure 4. Location of aluminum access tubes at a distance of 50 and $100 \mathrm{~cm}$ up and down each treatment.

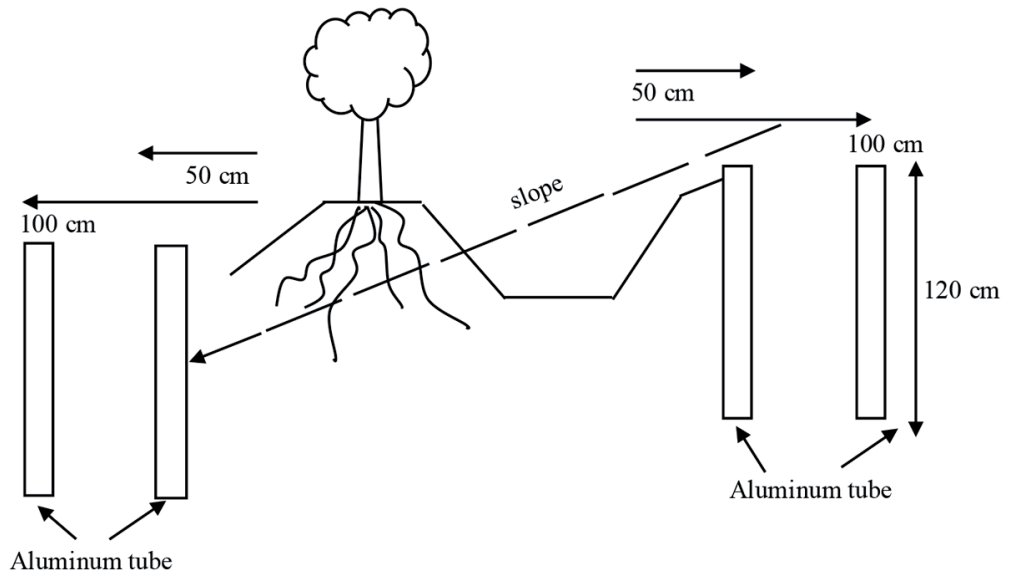




\section{RESULTS AND DISCUSSION}

\section{Effects of conservation techniques on SWC}

Annual rainfall was 372,768 , and $536 \mathrm{~mm}$ for 2007,2008 , and 2009 , respectively, and $80 \%$ of the annual rainfall was concentrated in May and August; however, in May 2008 the high intensity rains reached $370 \mathrm{~mm}$ (Figure 1). Results indicated that conservation systems allow higher SWC accumulation, especially in the years with higher rainfall (Figure 5); at 20-40 and 40-60 cm depth SWC was significantly ( $<$ < 0.05) higher in SB followed by IT and CO in the 3-yr period, whereas at 60-80 and 80-100 $\mathrm{cm}$ depth differences were significant only in the driest years (Table 1). The main differences

Figure 5. Soil water content at 20-40 and 40-60 cm depth during dry period for the $2007(\mathrm{~A}, \mathrm{~B}), 2008$ (C, D), and 2009 (E, F) seasons.
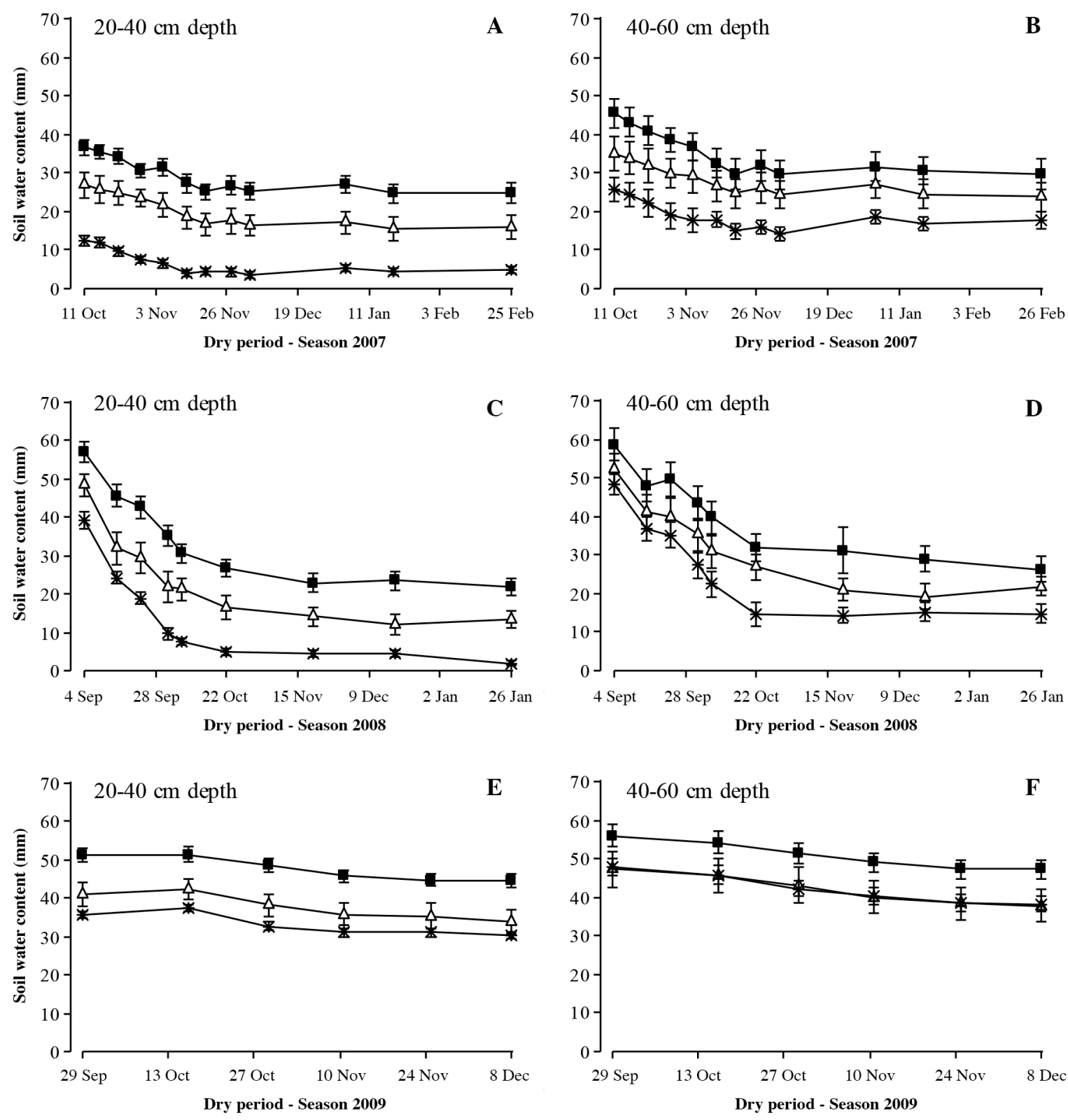

SB: Subsoiling with contour ridges; IT: infiltration trench; CO: control.

For each date different vertical bars refers to \pm standard deviation of the mean $(n=36)$. 
Table 1. Average soil water content at different depth in three conservation techniques from 2007 to 2009.

\begin{tabular}{|c|c|c|c|c|c|}
\hline \multirow[b]{2}{*}{ Year } & \multirow[b]{2}{*}{ Treatments } & \multicolumn{4}{|c|}{ Soil depth $(\mathrm{cm})$} \\
\hline & & $20-40$ & $40-60$ & $60-80$ & $80-100$ \\
\hline \multirow{3}{*}{2007} & SB & $29.12 a$ & $34.99 a$ & $43.19 a$ & 55569 \\
\hline & IT & $20.01 \mathrm{~b}$ & $28.05 \mathrm{~b}$ & $39.83 \mathrm{ab}$ & $55.28 \mathrm{a}$ \\
\hline & $\mathrm{CO}$ & $6.52 \mathrm{c}$ & $18.74 \mathrm{c}$ & $37.40 \mathrm{~b}$ & $47.12 \mathrm{~b}$ \\
\hline \multirow{3}{*}{2008} & SB & $34.01 \mathrm{a}$ & $39.74 a$ & $47.81 \mathrm{a}$ & $56.42 \mathrm{ab}$ \\
\hline & IT & $23.18 b$ & $32.05 \mathrm{~b}$ & $42.20 \mathrm{a}$ & $52.07 \mathrm{~b}$ \\
\hline & $\mathrm{CO}$ & $12.78 \mathrm{c}$ & $25.44 \mathrm{c}$ & $48.33 a$ & $62.62 \mathrm{a}$ \\
\hline \multirow[t]{3}{*}{2009} & SB & $47.77 \mathrm{a}$ & $50.83 \mathrm{a}$ & $55.20 \mathrm{a}$ & $62.80 \mathrm{ab}$ \\
\hline & IT & $37.81 \mathrm{~b}$ & $42.02 \mathrm{~b}$ & $48.53 b$ & $57.99 \mathrm{~b}$ \\
\hline & $\mathrm{CO}$ & $33.09 \mathrm{c}$ & $42.16 \mathrm{c}$ & $55.71 \mathrm{a}$ & $66.43 \mathrm{a}$ \\
\hline
\end{tabular}

SB: Subsoiling with contour ridges, IT: infiltration trench, CO: control.

Different letters in the same column indicate differences for treatments according to Tukey's test $(\mathrm{P}<0.05)$.

in SWC among establishment systems were between 20 and $60 \mathrm{~cm}$ depth (Figure 5). The decrease in SWC is explained by the fact that the evaluations were carried out between September and December, this is when rainfall decreases and evaporation and temperature increase. At the start of the season of the driest year (2007) the SWC at 20-40 cm in SB was $27 \%$ and $68 \%$ higher than in IT and CO, respectively, whereas in the wettest year (2008) these differences were $14 \%$ and $32 \%$, respectively. The decline in SWC from the beginning to the end of the evaluations was more pronounced in $\mathrm{CO}$ compared to SB and IT, in both driest and wetter years (Figure 5).

Each season was characterized by a period of water accumulation in the soil and a period of water reduction in the profile due to a decrease in rainfall. Conservation techniques showed higher efficiency in capturing rainwater during the winter and allowing greater SWC availability during the dry season (Makurira et al., 2011; Castaldi and Chiocchini, 2012; Nichols et al., 2012). Lower water content in the profile, such as the one observed in the control treatment (CO), would indicate increased surface runoff; this is a factor of great interest for this area that is characterized by severely eroded soils (Martínez et al., 2011; 2012).

Among the conservation systems, IT systems have been recognized by various authors as a technique that promotes SWC, especially in arid zones (Makurira et al., 2009; 2011; Lenka et al., 2012). Contrary to expectations, this technique was not the most effective even with values similar to the CO treatment that were observed in the 2009 season; it is open to discussion that part of the water captured in the trenches was lost through evaporation. Makurira et al. (2007) mentioned that topography sometimes diverts surface runoff from the highest areas towards the ITs; according to our field observations, water captured by ITs was evident after rain events (Figure 2b).

It has been pointed out that when compaction is deep, more radical measures such as subsoiling are necessary; the most obvious benefit of subsoiling is the breaking up of compacted subsoil layers to improve root growth and increase rainfall infiltration in the soil profile (Martínez et al., 2011). Results revealed that SB was much more effective in promoting higher water infiltration towards lower horizons; although the breakdown by subsoiling was up to $40 \mathrm{~cm}$ depth, higher SWC was observed up to $60 \mathrm{~cm}$ (Figure 5). An increased infiltration of water, reduces soil crusting, compaction and erosion (Corbeels et al., 2019; Kumar et al., 2020). Finally, it was observed that the slope effect promoted higher SWC in the system where the species were established and this would have helped its adaptation.

\section{Effect of conservation agriculture techniques on establishment of tree species}

Our results showed that drought conditions declined tree growth and increased the tree mortality. However, conservation techniques had a significant effect on plant height, crown diameter and trunk diameter in the three evaluated species (Table 2 and Figure 6). Plant height in C. proliferus was higher in IT $>\mathrm{SB}>\mathrm{CO}$, while in $Q$. suber it was higher in $\mathrm{SB}>$ IT > CO; $Q$. saponaria exhibited similar growth in both conservation systems, but it was significantly higher $(\mathrm{P}<0.05)$ than in CO. The survival rate of Q. saponaria at the end of the experiment (2011) was lower in the CO system (57\%), while C.proliferus and $Q$. suber had similar survival rates in the three systems (97\% and 87\%, respectively) (Figure 7).

As mentioned by Lv et al. (2019) drought stress decreases the growth and development by reducing photosynthetic rate; however, SWC enhances the growth increment in semi-arid climates (Kumar et al., 2020). Scarce SWC in the dry season (summer) and the high apparent density affected the growth and survival of the three species under study when these 
Table 2. Plant height and crown diameter of Cytisus proliferus, Quercus suber, and Quillaja saponaria from 2008 to 2011.

\begin{tabular}{|c|c|c|c|c|c|c|}
\hline Evaluation & Tree species & Treatments & 2008 & 2009 & 2010 & 2011 \\
\hline \multirow[t]{9}{*}{ Plant height, $\mathrm{cm}$} & \multirow[t]{3}{*}{ C.proliferus } & SB & $136 b$ & $108 \mathrm{~b}$ & $156 \mathrm{~b}$ & $184 b$ \\
\hline & & IT & $174 \mathrm{a}$ & $122 \mathrm{a}$ & $175 \mathrm{a}$ & $219 a$ \\
\hline & & $\mathrm{CO}$ & $133 b$ & $95 \mathrm{c}$ & $147 b$ & $150 \mathrm{c}$ \\
\hline & \multirow[t]{3}{*}{ Q. suber } & SB & $56 \mathrm{a}$ & $69 a$ & $76 a$ & $109 a$ \\
\hline & & IT & $56 \mathrm{a}$ & $63 a$ & $70 \mathrm{a}$ & $91 b$ \\
\hline & & $\mathrm{CO}$ & $54 \mathrm{a}$ & $53 b$ & $57 \mathrm{~b}$ & $70 \mathrm{c}$ \\
\hline & \multirow[t]{3}{*}{ Q. saponaria } & SB & $75 \mathrm{a}$ & $86 a$ & $108 \mathrm{a}$ & $105 \mathrm{ba}$ \\
\hline & & IT & $78 \mathrm{a}$ & $87 a$ & $102 \mathrm{a}$ & $118 \mathrm{a}$ \\
\hline & & $\mathrm{CO}$ & $70 \mathrm{a}$ & $70 \mathrm{~b}$ & $83 b$ & $92 b$ \\
\hline \multirow[t]{9}{*}{ Crown diameter, $\mathrm{cm}$} & \multirow[t]{3}{*}{ C. proliferus } & SB & $171 \mathrm{a}$ & $172 \mathrm{a}$ & $183 a$ & $211 \mathrm{a}$ \\
\hline & & IT & $177 \mathrm{a}$ & $182 \mathrm{a}$ & $201 \mathrm{a}$ & $223 a$ \\
\hline & & $\mathrm{CO}$ & $111 \mathrm{~b}$ & $120 \mathrm{~b}$ & $137 \mathrm{~b}$ & $150 \mathrm{~b}$ \\
\hline & \multirow[t]{3}{*}{ Q. suber } & SB & $67 a$ & $80 \mathrm{a}$ & $94 \mathrm{a}$ & $119 \mathrm{a}$ \\
\hline & & IT & $57 \mathrm{~b}$ & $61 \mathrm{~b}$ & $81 \mathrm{~b}$ & $91 \mathrm{~b}$ \\
\hline & & $\mathrm{CO}$ & $58 \mathrm{~b}$ & $58 \mathrm{~b}$ & $73 b$ & $72 c$ \\
\hline & \multirow[t]{3}{*}{ Q. saponaria } & SB & $62 \mathrm{a}$ & $68 \mathrm{a}$ & $98 \mathrm{a}$ & $109 a$ \\
\hline & & IT & $60 \mathrm{a}$ & $68 \mathrm{a}$ & $93 \mathrm{a}$ & $105 \mathrm{a}$ \\
\hline & & $\mathrm{CO}$ & $42 \mathrm{~b}$ & $54 \mathrm{a}$ & $71 \mathrm{~b}$ & $83 b$ \\
\hline
\end{tabular}

SB: Subsoiling with contour ridges; IT: infiltration trench; CO: control.

Different letters in the same column indicate differences for treatments according to Tukey's test $(\mathrm{P}<0.05)$.

Figure 6. Trunk diameter of Cytisus proliferus (A), Quercus suber (B), and Quillaja saponaria (C), in subsoiling with contour ridges (SB), infiltration trench (IT), and control (CO) for 2008 and 2011.
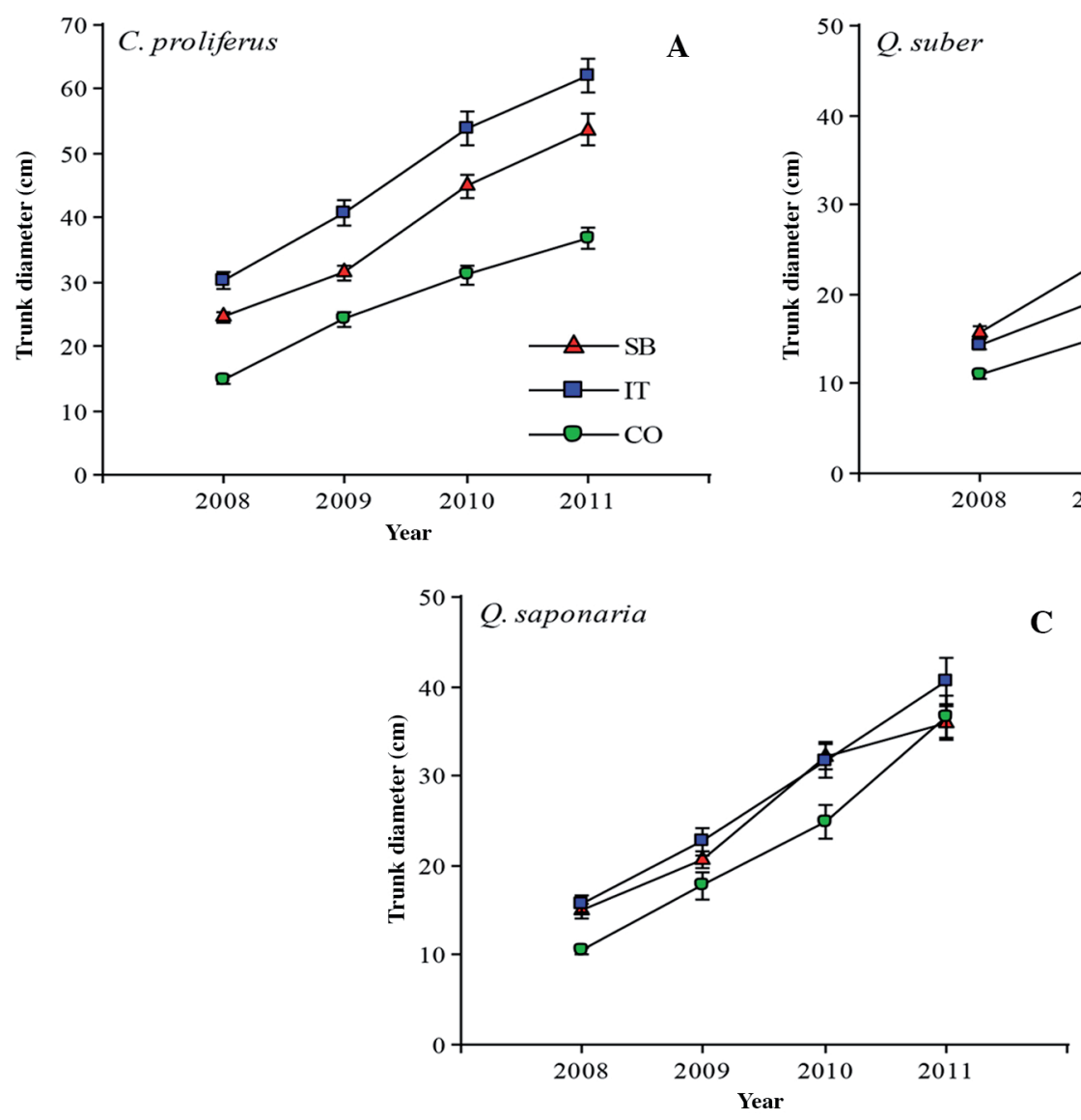

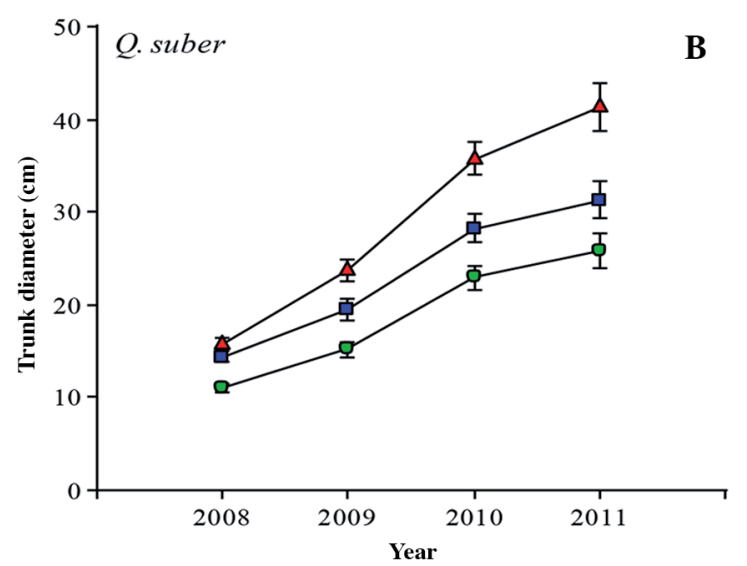

C

For each year different vertical bars refers to \pm standard deviation of the mean $(n=90)$. 
Figure 7. Survival rate of Cytisus proliferus, Quercus suber and Quillaja saponaria in the second (2008) and fifth (2011) seasons in subsoiling with contour ridges (SC), infiltration trench (IT) and control (CO).

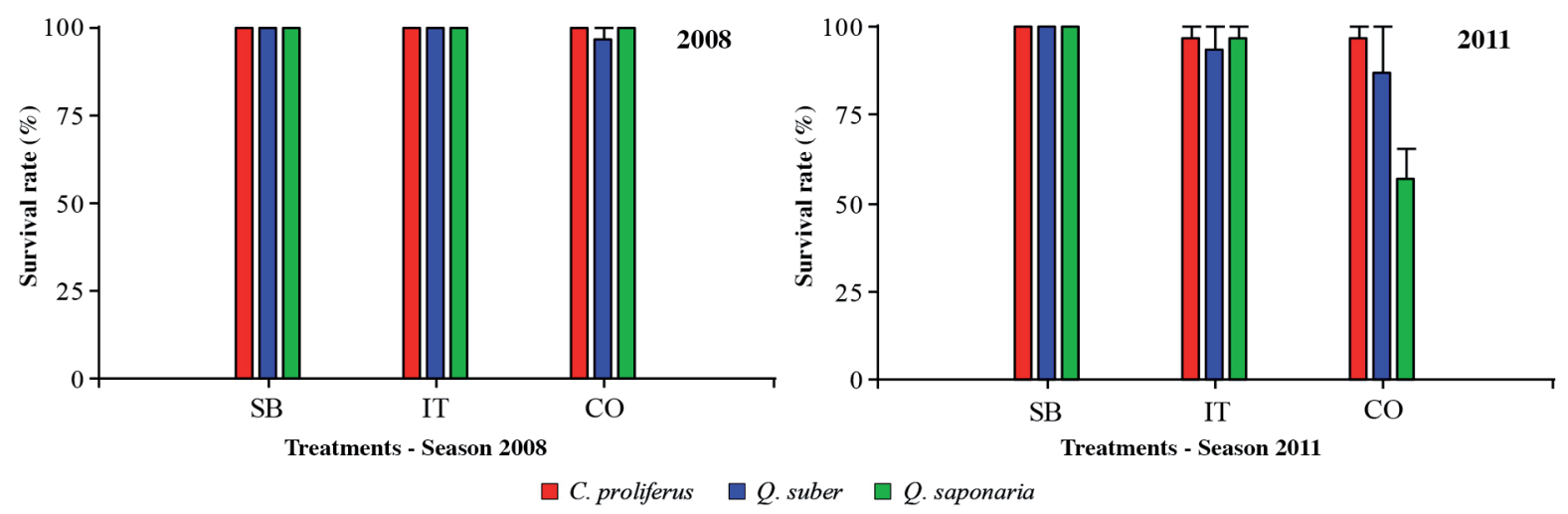

For each treatment different vertical bars refers to \pm standard deviation of the mean $(n=90)$.

were established without water and soil conservation techniques (Frankl et al., 2012; Fu et al., 2012; Guto et al., 2012; Kouba et al., 2012). The $C$. proliferus and $Q$. suber species exhibited better adaptation and rapid growth in soils without compaction problems as found in the two conservation techniques; however, IT production had a higher economic and human cost. On the other hand, higher growth of $Q$. suber in SB indicated that growth is higher in soils with higher soil water availability (Figure 6). The establishment and growth of $Q$. saponaria was independent of soil management, but its major disadvantage was survival when it was established without any conservation technique. This concurs with findings reported by Donoso et al. (2011), who indicate that high water restriction affects the physiology of this species, provokes a reduction of stomatal conductance, net photosynthesis, and transpiration, and produces lower leaf and root biomass.

\section{CONCLUSIONS}

Although infiltration trenches provided adequate conditions for establishing trees, they did not promote higher soil water content. A much simpler technique was subsoiling with ridges, which shows great potential for these conditions by promoting highest water content in the profile and a successful tree establishment. Cytisus proliferus exhibited better adaptation and rapid growth in the infiltration trenches, whereas the growth of Quillaja saponaria exhibited higher growth in subsoiling with ridges. Establishment and growth of $Q$. saponaria was independent of soil management; however, it exhibited lower survival when it was established without any conservation technique. These results show that subsoiling with contour ridges should be considered as an innovative conservation technique in planning agroforestry systems for severely degraded granitic soils with high slopes in Mediterranean climates.

\section{ACKNOWLEDGEMENTS}

This study was funded by the DESIRE Project (037046) of the European Union entitled "Desertification mitigation and land remediation - a global approach for local solutions" together with the research agreement on conservation practices between the Servicio Agrícola and Ganadero (SAG).

\section{REFERENCES}

Alfaro, M., Dube, F., and Zagal, E. 2018. Soil quality indicators in an Andisol under different tree covers in disturbed Nothofagus forests. Chilean Journal of Agricultural Research 78:106-116. doi:10.4067/S0718-58392018000100106.

Aranda, I., Forner, A., Cuesta, B., and Valladares, F. 2012. Species-specific water use by forest tree species: From the tree to the stand. Agricultural Water Management 114:67-77.

Biazin, B., Sterk G., Temesgen, M., Abdulkedir, A., and Stroosnijder, L. 2012. Rainwater harvesting and management in rainfed agricultural systems in sub-Saharan Africa - A review. Physics and Chemistry of the Earth 47-48:139-151. 
Camarasa-Belmonte, A.M., and Soriano, J. 2014. Empirical study of extreme rainfall intensity in a semi-arid environment at different time scales. Journal of Arid Environments 100-101:63-71.

Castaldi, F., and Chiocchini, U. 2012. Effects of land use changes on badland erosion in clayey drainage basins, Radicofani, Central Italy. Geomorphology 169-170:98-108.

CIREN. 2010. Determinación de la erosión actual y potencial de los suelos de Chile. Publicación Nº139. 285 p. Centro de Información de Recursos Naturales (CIREN), Santiago, Chile.

Corbeels, M., Cardinael, R., Naudin, K., Guibert, H., and Torquebiau, E. 2019. The 4 per 1000 goal and soil carbon storage under agroforestry and conservation agriculture systems in sub-Saharan Africa. Soil and Tillage Research 188:16-26.

de Miguel, J.M., Martín-Forés, I., Acosta-Gallo, B., del Pozo, A., Ovalle, C., Sánchez-Jardón, L., et al. 2016. Non-random co-occurrence of native and exotic plant species in Mediterranean grasslands. Acta Oecologica 77:18-26.

Del Pozo, A., y P. Del Canto. 1999. Áreas agroclimáticas y sistemas productivos en la VII y VIII Regiones. Instituto de Investigaciones Agropecuarias (INIA), INIA Quilamapu, Chillán, Chile.

Donoso, S., Peña, K., Pacheco, C., Luna, G., and Aguirre, A. 2011. Physiological and growth response in Quillaja saponaria and Cryptocarya alba plants under restricted water conditions. Bosque 32:187-195.

Frank1, A., Poesen, J., Deckers, J., Haile, M., and Nyssen, J. 2012. Gully head retreat rates in the semi-arid highlands of Northern Ethiopia. Geomorphology 173-174:185-195.

Fu, C., Chen, J., Dong, L., and Jiang, H. 2012. Field investigation and modeling of runoff generation in a granitic catchment in Zhuhai, China. Journal of Hydrology 458-459:87-102.

Gaspar, P., Mesías, F.J., Escribano, M., Rodríguez, A., and Pulido, F. 2007. Economic and management characterization of dehesa farms: implications for their sustainability. Agroforestry Systems 71:151-162.

Govaerts, B., Sayre, K.D., Goudeseune, B., De Corte, P., Lichter, K., Dendooven, L., et al. 2009. Conservation agriculture as a sustainable option for the central Mexican highlands. Soil and Tillage Research 103:222-209.

Guto, S.N., de Ridder, N., Giller, K.E., Pypers, P., and Vanlauwe, B. 2012. Minimum tillage and vegetative barrier effects on crop yields in relation to soil water content in the Central Kenya highlands. Field Crops Research 132:129-138.

Kouba, Y., Camarero, J.J., and Alados, C.L. 2012. Roles of land-use and climate change on the establishment and regeneration dynamics of Mediterranean semi-deciduous oak forests. Forest Ecology and Management 274:143-150.

Kumar, R., Bhatnagar, P.R., Kakade, V., and Dobhal, S. 2020. Tree plantation and soil water conservation enhances climate resilience and carbon sequestration of agro ecosystem in semi-arid degraded ravine lands. Agricultural and Forest Meteorology 282-283:107857. doi.org/10.1016/j.agrformet.2019.107857.

Labrière, N., Locatelli, B., Laumonier, Y., Freycon, V., and Bernoux, M. 2015. Soil erosion in the humid tropics. A systematic quantitative review. Agriculture, Ecosystems and Environment 203:127-139.

Lal, R. 2019. Accelerated soil erosion as a source of atmospheric $\mathrm{CO}_{2}$. Soil and Tillage Research 188:35-40.

Lenka, N.K., Choudhury, P.R., Sudhishri, S., Dass, A., and Patnaik, U.S. 2012. Soil aggregation, carbon build up and root zone soil moisture in degraded sloping lands under selected agroforestry based rehabilitation systems in eastern India. Agriculture, Ecosystems and Environment 150:54-62.

Lv, J., Zong, X., Ahmad, A.S., Wu, X., Wu, C., Li, Y., et al. 2019. Alteration in morpho-physiological attributes of Leymuus chinensis (Trin.) Tzvelev by exogenous application of brassinolide under varying levels of drought stress. Chilean Journal of Agricultural Research 80:61-71.

Makurira, H., Savenije, H.H.G., and Uhlenbrook, S. 2007. Towards a better understanding of water partitioning processes for improved smallholder rainfed agricultural systems: a case study of Makanya catchment, Tanzania. Physics and Chemistry of the Earth 32:1082-1089.

Makurira, H., Savenije, H.H.G., Uhlenbrook, S., Rockström, J., and Senzanje, A. 2009. Investigating the water balance of onfarm techniques for improved crop productivity in rainfed systems: A case study of Makanya catchment, Tanzania. Physics and Chemistry of the Earth 34:93-98.

Makurira, H., Savenije, H.H.G., Uhlenbrook, S., Rockström, J., and Senzanje, A. 2011. The effect of system innovations on water productivity in subsistence rainfed agricultural systems in semi-arid Tanzania. Agricultural Water Management 98:1696-1703.

Martínez, I., Ovalle, C., del Pozo, A., Uribe, H., Valderrama, N., Prat, C., et al. 2011. Influence of conservation tillage and soil water content on crop yield in dryland compacted Alfisol of central Chile. Chilean Journal of Agricultural Research 71:615-622.

Martínez, I., Prat, C., Ovalle, C., del Pozo, A., Stolpe, N., and Zagal, E. 2012. Subsoiling improves conservation tillage in cereal production of severely degraded Alfisols under Mediterranean climate. Geoderma 189-190:10-17.

Moya, E., San Martín Gamboa, R., and Apablaza Hidalgo, G.E. 2010. Evaluation of a Quillaja saponaria saponin extract for control of powderly mildew of wheat and squash. Agro Sur 38:87-96.

Mupangwa, W., Twomlow, S., and Walker, S. 2012. Dead level contours and infiltration pits for risk mitigation in smallholder cropping systems of southern Zimbabwe. Physics and Chemistry of the Earth 47-48:166-172.

Nichols, M.H., McReynolds, K., and Reed, C. 2012. Short-term soil moisture response to low-tech erosion control structures in a semiarid rangeland. Catena 98:104-109. 
Ovalle, C., Del Pozo, A., Casado, M., Acosta, B., and de Miguel, J. 2006. Consequences of landscape heterogeneity on grassland diversity and productivity in the espinal agroforestry system of central Chile. Landscape Ecology 21:585-594.

Pausas, J.G., Pereira, J.S., and Aronson, J. 2009. The tree. p. 11-21. In Aronson, J., Pereira, J.S., and Pausas, J.G. (eds.) Cork oak woodlands on the edge: Ecology, adaptive management, and restoration. Island Press, Washington, D.C., USA.

Rolo, V., and Moreno, G. 2019. Shrub encroachment and climate change increase the exposure to drought of Mediterranean wood-pastures. Science of the Total Environment 660:550-558.

Stolpe, N.B. 2006. Descripción de los principales suelos de la VIII Región de Chile. 84 p. Universidad de Concepción, Facultad de Agronomía, Chillán, Chile.

Vicente-Serrano, S.M., Lasanta, T., and Gracia, C. 2010. Aridification determines changes in forest growth in Pinus halepensis forests under semiarid Mediterranean climate conditions. Agricultural and Forest Meteorology 150:614-628. 